Annals of Warsaw University of Life Sciences - SGGW

Land Reclamation No 48 (3), 2016: 221-231

(Ann. Warsaw Univ. of Life Sci. - SGGW, Land Reclam. 48 (3), 2016)

\title{
Impact of the moisture content in medium sands on CPTU test results
}

\author{
ŁUKASZ ZAWADZKI, MAREK BAJDA \\ Department of Geotechnical Engineering, Warsaw University of Life Sciences - SGGW
}

\begin{abstract}
Impact of the moisture content in medium sands on CPTU test results. Soils occurring in the soil "active zone" are in contact with the surface and are directly influenced by external factors (mainly climatic changes) that cause variation in their parameters over time. Dynamic and uncontrolled changes of soil properties e.g. due to rainfall and evapotranspiration processes may affect field test results leading to the misinterpretation of the obtained data. This paper presents investigations on the influence of moisture content changes in sandy soils on CPTU results. For this purpose, a field ground model has been constructed and five CPTU tests with a different moisture content of soil were carried out. During the investigations, the tip resistance $\left(q_{c}\right)$, friction on sleeve $\left(f_{s}\right)$, and pore water pressure $\left(u_{2}\right)$ were measured. Moreover, a TDR probe was applied to determine the distribution of the moisture content in the studied soil columns. Differences between CPT results obtained in saturated and unsaturated soils have been shown. Furthermore, a simple equation to correct the tip resistance value due to the impact of the degree of saturation has been proposed.
\end{abstract}

Key words: CPTU, unsaturated soils, field testing, saturation degree

\section{INTRODUCTION}

The cone penetration test (CPT) is one of the most widely used methods for acquisition of geotechnical data. It provides information for subsurface recognition, estimation of geotechnical parameters and data for geotechnical design (Lunne et al. 1997, Młynarek and Wierzbicki 2007, Lech et al. 2008). The test procedure and data interpretation have been developing since 1900 (Sanglerat 1972, Lunne et al. 1997), but the method still requires further research on parameters affecting the measurements and proper data rendering.

One of the areas that needs further research is the unsaturated behavior of soils. Such soils are widespread around the world and expand even more due to climate change and human activities such as: covering the land surface with impermeable pavements that causes reduction in the amount of infiltrating water, use of drainage that lowers the water table, building of earth dams and interference in the water regime, etc. Properties of the unsaturated soils depend on many factors, such as: soil type, structure, density, pore size and suction resulting from surface tension of water and adhesion (Russell et al. 2010). Furthermore, soils occurring at shallow depths are in constant contact with the surface, and thus directly influenced by external factors, such as rainfall and evapotranspiration processes that cause dynamic changes in the properties of these soils over time. Therefore, determination of the parameters of unsaturated soils is a very complex task that engineers have to 
face during design and accomplishment of constructions, including foundations, embankments, pavements, airfields and slopes (Pournaghiazar et al. 2010, Russell et al. 2010).

At present, the interpretation of CPT tests is based mostly on well-established correlations determined for fully saturated or dry soils (two phases material) (Robertson and Campanella 1983, Robertson 1990, Lunne et al. 1997, Jamiolkowski et al. 2003) and little work has been conducted on the investigation of CPT results for unsaturated soils (more than two phases material). Only a few studies have been undertaken in recent years in modified calibration chambers in laboratory (Russell et al. 2010, Pournaghiazar et al. 2010, 2011, 2013, Yang and Russell 2013, 2016) and field conditions (Lehane et al. 2004, Collins and Miller 2014). Moreover, Eurocode 7 (PN-EN 1997-1, PN-EN 1997-2) and related ISO standards (EN ISO 22476-1, EN ISO 22476-12) do not contain any information on the interpretation of field test data in unsaturated soils. For this reason, due to lack of guidance, engineers commonly apply correlations developed for saturated or dry soils to interpret the CPT results obtained in unsaturated conditions, which may lead to the misinterpretation of obtained data and estimated soil properties (Pournaghiazar et al. 2010).

Correlation between soil properties and cone penetration test data are usually determined in laboratory controlled conditions in a calibration chamber or a centrifuge under fixed boundary conditions (Phillips and Valsangkar 1987, Ghionna and Jamiolkowski 1991, Mayne and Kulhawy 1991, Schnaid and Houlsby 1991, Gui and Bolton 1998, Salgado et al. 1998, Bałachowski 2006, Tufenkjian et al. 2010). Depending on the test scale, miniature or full-sized probes are used. The commonly used boundary conditions include: $\mathrm{BC} 1$ ( $\sigma_{h}=$ const., $\sigma_{v}=$ const.), $\mathrm{BC} 2\left(\varepsilon_{h}=0, \varepsilon_{v}=0\right), \mathrm{BC} 3$ $\left(\varepsilon_{h}=0, \sigma_{v}=\right.$ const.), BC4 ( $\sigma_{h}=$ const., $\varepsilon_{v}=0$ ), and BC5 (lateral stifness, $k=$ $=$ const., $\sigma_{v}=$ const.) (Salgado et al. 1998, Bałachowski 2006, Ahmadi and Robertson 2008, Bałachowski and $\mathrm{Ku}-$ rek 2008). Measurements in controlled laboratory conditions provide data for further analysis and reference for field test data interpretation.

This paper presents the results of CPTU tests carried out in a field ground model developed in a test site at the Warsaw University of Life Sciences - SGGW campus. The primary aim of this paper was to investigate the influence of the moisture content change in sandy soils on the results of the cone penetration test. For this purpose, five CPTU tests have been performed on soil columns with different moisture content. During each test, tip resistance $\left(q_{c}\right)$, sleeve friction $\left(f_{s}\right)$ and pore water pressure $\left(u_{2}\right)$ were logged. Moreover, TDR probes have been used to determine the distribution of the moisture content in the soil columns.

\section{MATERIAL AND METHODS}

The tests were carried out in a uniform medium Vistula sand from the vicinity of Warsaw (Fig. 1) in two soil columns. The properties of the tested soil are presented in Table 1. Soil columns were formed in $0.2 \mathrm{~m}$ compacted layers. Three CPTU tests (A, B, C) were performed for column 1 


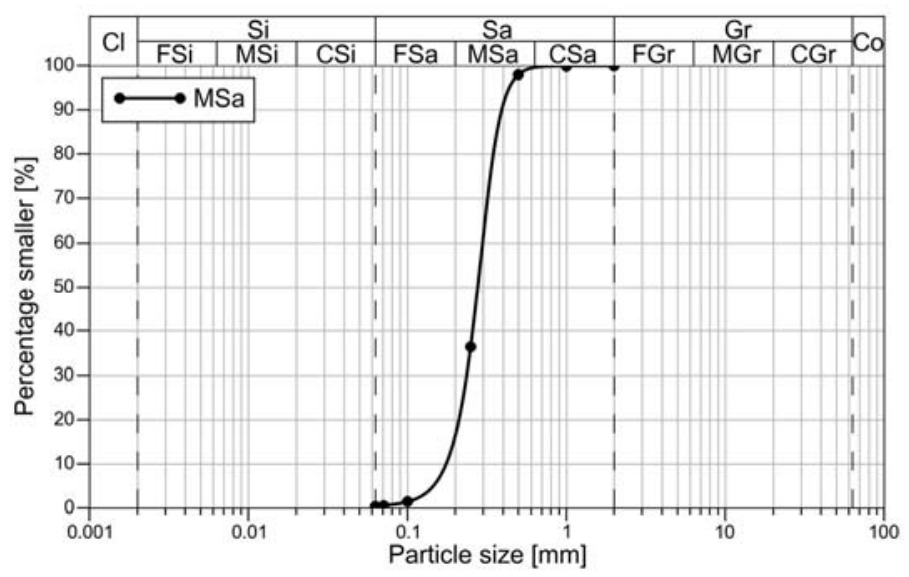

FIGURE 1. Particle size distribution curve for the tested soil

TABLE 1. Properties of the tested soil

\begin{tabular}{lccccc}
\hline Soil type & $C_{u}$ & $C_{c}$ & $D_{50}(\mathrm{~mm})$ & $\rho_{\mathrm{dmax}}\left(\mathrm{kg} / \mathrm{m}^{3}\right)$ & $\rho_{\mathrm{dmin}}\left(\mathrm{kg} / \mathrm{m}^{3}\right)$ \\
\hline MSa & 1.7 & 1.07 & 0.28 & 1700 & 1480 \\
\hline
\end{tabular}

and two CPTU tests (A, B) were performed for column 2 . The soil properties for each tested column are presented in Table 2. Between each test (A, B, C), the moisture content of the soil was changed to provide various test conditions. a piezometer to increase the water table to a desired level.

The test chamber and location of the measurement points in each soil column (A, B, C) are shown in Figure 2. The tests were performed in a cylindrical plastic

TABLE 2. Properties of the soil in the tested columns

\begin{tabular}{lccc}
\hline Soil column & $I_{D}(\%)$ & $\rho_{d}\left(\mathrm{~kg} / \mathrm{m}^{3}\right)$ & $e(-)$ \\
\hline Column 1 & 40 & $1560 \pm 16$ & 0.7 \\
\hline Column 2 & 75 & $1640 \pm 32$ & 0.62 \\
\hline
\end{tabular}

The change of the water content between each test was induced by moistening the soil columns. In the first soil column, the moistening was performed by wetting the soil from the top and bottom of the column with a piezometer. In the second soil column, moisture was controlled by change of water level. Water was applied from the bottom by chamber placed in soil at the SGGW campus (Fig. 2a). The inner diameter of the chamber was $0.82 \mathrm{~m}$ and the height was $1.20 \mathrm{~m}$. The bottom was open, restrained only by the soil lying below the chamber. Furthermore, a $0.2 \mathrm{~m}$ layer of impermeable clay was placed at the bottom to reduce water leakage during the measurements. Such conditions corre- 
a

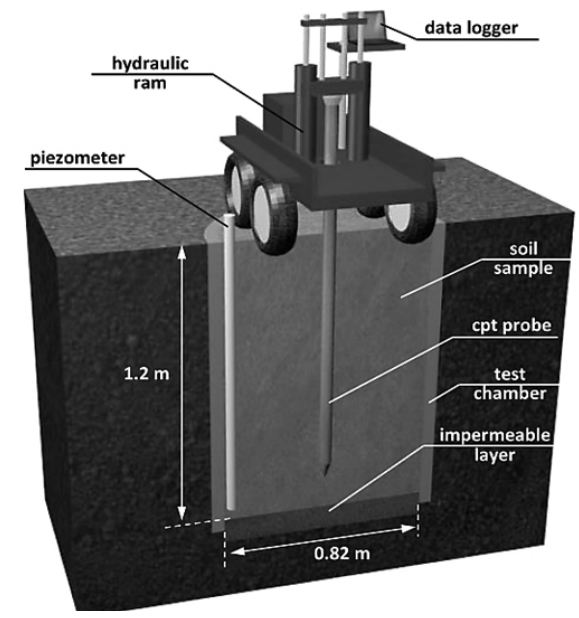

b

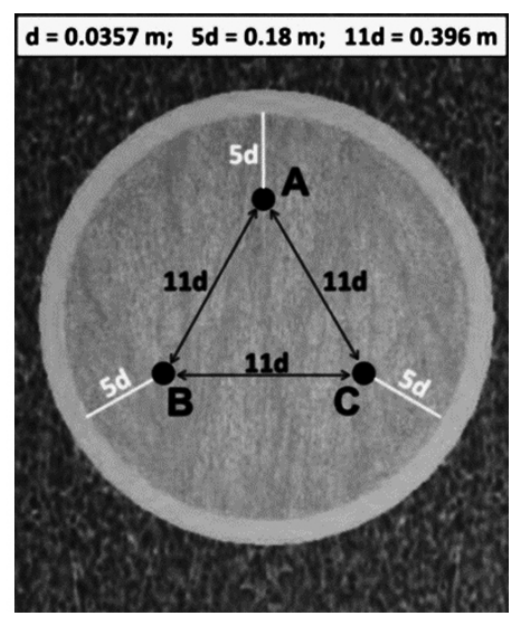

FIGURE 2. Test model: (a) scheme of measurement chamber; (b) location of measurement points in the test chamber cross-section

spond to BC5 boundary conditions with lateral stiffness, $k=$ const., $\sigma_{v}=$ const.

The ratio between the chamber diameter $\mathrm{D}$ and the probe diameter $d$ was $D / d=23$. According to e.g. Ghionna and Jamiolkowski (1991), Bolton and Gui (1993), Mayne (2006), a higher $D / d$ ratio is needed to avoid the influence of the boundary effects and reference calibration chamber tests directly on the field results. However, the main goal of this paper was to capture the impact of soil moisture content on the cone penetration test results. Therefore, all measurements were taken under the same boundary conditions, which makes the measurements comparable. The location of the measurement points was spread evenly in the cross-section of the soil columns (Fig. 2b) to ensure similar conditions for each test. Two main assumptions had been taken into account for selection of the test locations. First, the distance between the test points should be at least $10 d$. Second, the distance between the measurement point and the rigid wall of the chamber should be at least $5 d$; according to Phillips and Valsangkar (1987) and Salgado et al. (1998), the influence of the rigid side wall of the chamber can be omitted when the test is conducted at a distance greater than five times of the probe diameter and the penetration test is performed close only to one side of the chamber.

Other limitations that should be considered in the test are boundary conditions on top and bottom of the test chamber. It is well known that to mobilize full strength of soil the depth ratio $(z / d)_{\text {crit }}$ ( $z$ - depth of investigation, $d-$ cone diameter) dependent on relative density should be at least 5 $\div 20$ (Gui and Bolton 1998, Gui et al. 1998, Bałachowski 2015). Due to limited depth of investigation later in the article the interpretation of data below depth $0.2 \mathrm{~m}$ was considered what is equivalent to depth ratio $(z / d)_{\text {crit }} \approx 5$. On the other hand the impact of bottom boundary effects on performed 
CPTU test can be notice. This is caused by the influence of clay layer with different stiffness (Mlynarek et al. 2012) arranged in the bottom of test chamber. Considering above factors authors decided to maintain interpretation of data in depth interval $0.2 \div 1.0 \mathrm{~m}$.

Cone penetration tests were conducted using a standard piezocone with an apex angle of $60^{\circ}$, diameter of $3.57 \mathrm{~cm}\left(10 \mathrm{~cm}^{2}\right.$ of cross-sectional area) and pore pressure measurement in a $u_{2}$ position. The cone was being pushed into the soil column by a HYSON $200 \mathrm{kN}$ static cone penetrometer at a rate of $2 \mathrm{~cm} / \mathrm{s}$. The test set was equipped with a wired Touch-Screen data recording system. Measurements were recorded using Gorilla software (van den Berg). Tests were performed using a piezocone with measurement accuracy: $q_{c} \pm 1 \mathrm{kPa}$, $f_{s} \pm 1 \mathrm{kPa}, u_{2} \pm 1 \mathrm{kPa}$. Furthermore, TDR ThetaProbe ML3, with measurement accuracy of $1 \%$, and $\mathrm{HH} 2$ data logger were used after each CPTU test in order to determine the moisture content distribution in the soil column on the site. The degree of saturation, $\left(S_{r}\right)$ was calculated from TDR measurements and porosity. A TDR probe allows for measurement of the volume of water contained in the soil pores, $V_{w}[\%]$. When the soil porosity $-n[\%]$ (or TDR measurement of fully saturated soil, $V_{w}=V_{n}=n$ ) is known, the basic equation for calculating the degree of saturation can be used $\left(S_{r}=V_{w} / V_{n}\right)$.

\section{RESULTS AND DISCUSSION}

The results of CPTU measurements and profiles showing the degree of saturation for each test are shown in Figures 3 and 4. It can be noticed that the degree of saturation for sandy soils has significant impact on the soil strength, and thus on the CPTU test results. As can be seen in Figures 3 and 4, the change of saturation degree $\left(S_{r}\right)$ from $\approx 0.2$ to 1.0 is associat-

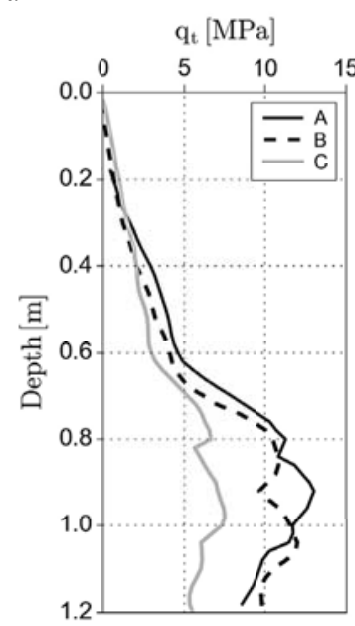

b

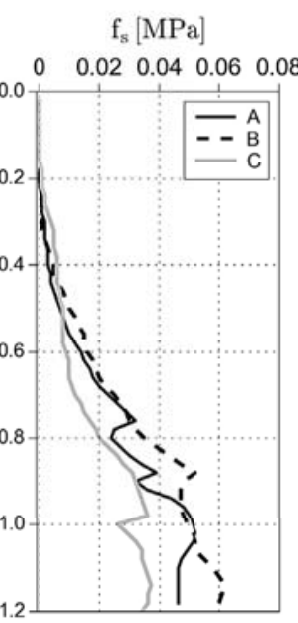

$\mathrm{c}$

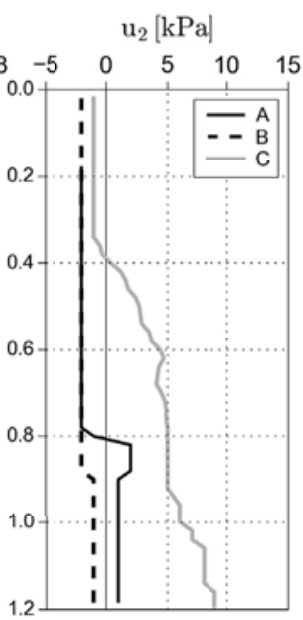

d

FIGURE 3. CPTU test results in soil column 1 (A, B, C - test points according to Fig. 2): (a) corrected cone resistance, $q_{t}$; (b) sleeve friction, $f_{s}$; (c) pore pressure measured behind cone, $u_{2}$; (d) degree of saturation, $S_{r}$ 
a $\mathrm{b} \quad \mathrm{c}$ d

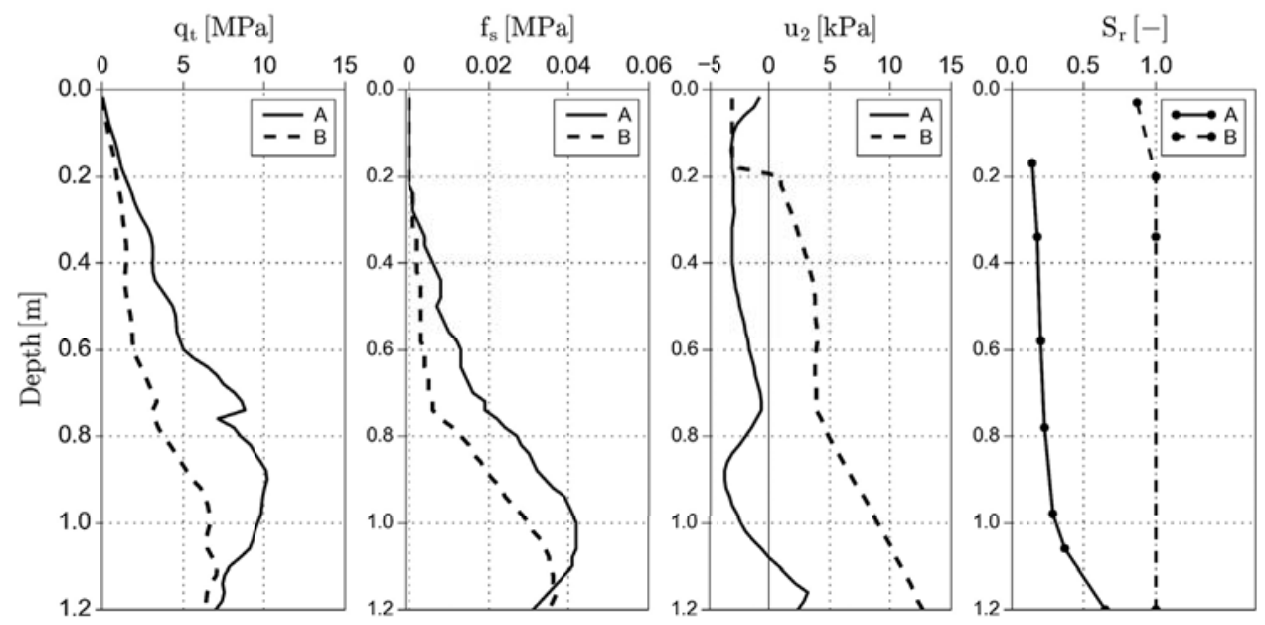

FIGURE 4. CPTU test results in soil column 2 (A, B, C - test points according to Fig. 2): (a) corrected cone resistance, $q_{t}$; (b) sleeve friction, $f_{s}$; (c) pore pressure measured behind cone, $u_{2}$; (d) degree of saturation, $S_{r}$

ed with the decrease of parameters measured during the CPTU test. Reduction of the soil strength can be observed in both measurements: cone resistance, $q_{c}$ and sleeve friction, $f_{s}$, wherein a decrease in the measured values is even more than double. For example, in soil column 2 at the depth of $0.8 \mathrm{~m}$, the change of the saturation degree from 0.24 to 1.0 resulted in the change of tip resistance from 8.51 to $3.76 \mathrm{MPa}$ (a decrease of more than $50 \%$ ) and of sleeve friction from 0.027 to $0.013 \mathrm{MPa}$ (a decrease of more than $50 \%$ ). Thus, the values measured in unsaturated soils are substantially higher than the values obtained from measurements on fully saturated soils and can't be used directly to calculate geotechnical parameters (the quotient between the $Q_{t}$ values in saturated and unsaturated sands is presented in Figs $5 \mathrm{~b}$ and $6 \mathrm{~b}$ ). The decrease in the measured values during the tests is greater when the saturation of soil is higher, whereas the measurements of induced pore pressure in the unsaturated zone are not reliable and do not allow for determination of the soil saturation (Figs $3 c$ and $4 c$ ). Therefore, it seems important to use another tool to determine the soil moisture in the active zone during a CPTU test, which would allow for correction of the measured values. On the other hand, the measurements of pore water pressure allow to determinate unsaturated zones, and can be used for defining layers, in which the moisture content should be taken into account in data interpretation.

During penetration the measured values are affected by many factors. For tests conducted on sands with constant characteristics the change of cone resistance can be described by the function (Jamiolkowski et al. 2003, Młynarek 2007):

$q_{t}=f\left(I_{D}, \sigma_{v 0}, S_{r}, v\right)$ 
a

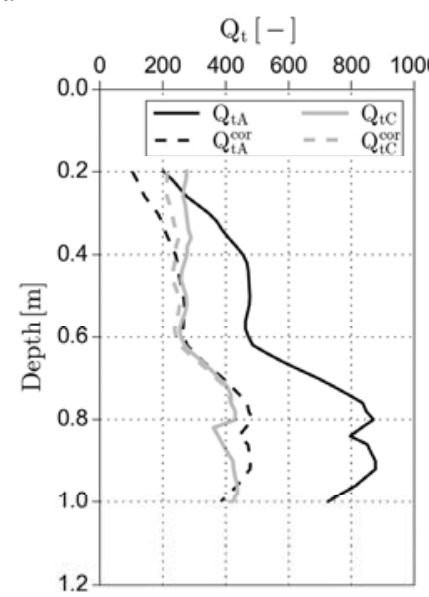

b

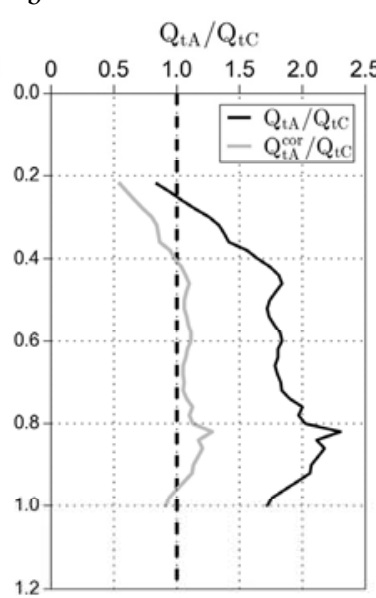

c

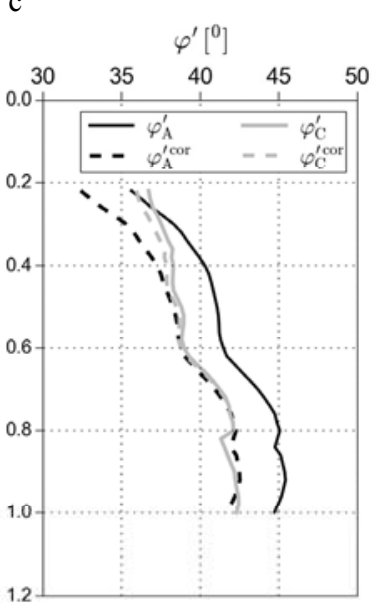

FIGURE 5. Comparison between the measured and corrected values in soil column 1 (A, C-test points according to Fig. 2): (a) normalized cone resistance, $Q_{t}$; (b) statistical analysis; (c) angle of internal friction before and after correction

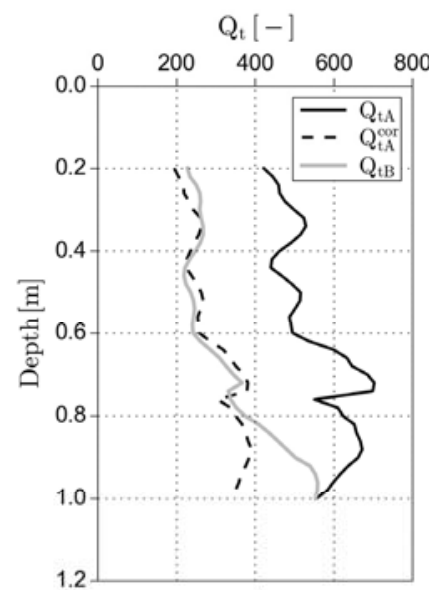

$\mathrm{b}$

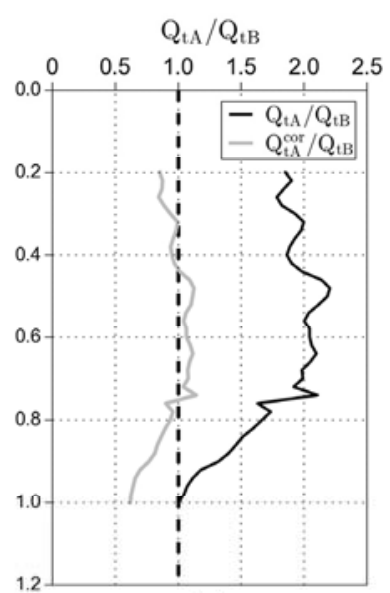

$\mathrm{c}$

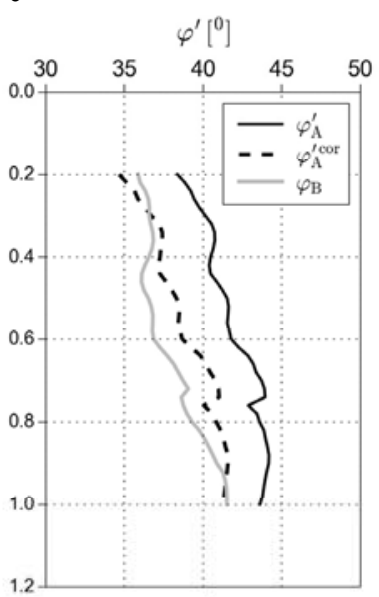

FIGES 6. Comparison between the measured and corrected values in soil column 2 (A, B - test points according to Fig. 2): (a) normalized cone resistance, $Q_{t}$; (b) statistical analysis; (c) angle of internal friction before and after correction

where:

$I_{D}\left(D_{R}\right)$ - soil relative density;

$\sigma_{v 0}-$ soil vertical stress;

$S_{r}$ - degree of saturation,

$v$ - rate of penetration (constant during test $2 \mathrm{~cm} / \mathrm{s}$ ).
Due to fact that compared tests were conducted on the same soil sample (three tests on soil column 1 and two tests on soil column 2) the influence of relative density can be omitted (relative density constant at certain depth). To eliminate influence of vertical stress on cone re- 
sistance the normalized value of cone resistance $\left(Q_{t}\right)$ have been used during analysis:

$$
Q_{t}=\frac{q_{t}-\sigma_{v 0}}{\sigma_{v 0}^{\prime}}
$$

Thus after these assumptions it can be assumed that the degree of saturation was the main factor influencing the variability of cone resistance between compared tests.

As can be observed, the direct use of the measured values obtained in the unsaturated zone for the determination of geotechnical parameters can lead to overestimation of the design parameters. In consequence, it can result in negative effects on structures designed in such conditions. This suggests the necessity of correcting the measurements taken in unsaturated conditions. For the tests performed in medium sands, the normalized cone resistance value can be corrected using the degree of water saturation $\left(S_{r}\right)$ and void ratio $(e)$ :

$$
Q_{t}^{c o r}=Q_{t} \cdot S_{r}^{1-e}
$$

Comparison between the measured and corrected values of $Q_{t}$ for extreme measurements using equation (3) are shown in Figures 5 and 6 . Table 3 presents the statistical analysis for the depth interval $0.2 \div 1.0 \mathrm{~m}$. It can be noticed that the average values of normalized cone resistance obtained for unsaturated sands were higher at about $1.73 \pm 0.30$ times for column 1 , and $1.79 \pm 0.34$ times for column 2. After correcting $Q_{t}$ using equation 1 , the average values were 1.01 \pm 0.16 times lower for column 1 and 0.94 \pm 0.15 times higher for column 2 . Use of the proposed equation leads to the reduction of $Q_{t}$ values obtained in unsaturated conditions due to the change of the degree of saturation, which takes the corrected values closer to those acquired in fully saturated conditions. However, the presented method of correction was based only on a few tests obtained for sandy soils, so confirmation of its reliability requires further studies.

The example of the difference between the angle of internal friction calculated for saturated and unsaturated conditions and corrected values was presented in Figures 5c and 6c. In the example, the following equation was used (Mayne 2006):

$$
\varphi^{\prime}=17.6+11.0 \cdot \log \left(q_{t 1}\right)
$$

where:

$q_{t 1}=\left(q_{t} / \sigma_{\text {atm }}\right) /\left(\sigma^{\prime}{ }^{\prime} 0 / \sigma_{a t m}\right)^{0.5}$ is the stressnormalized tip resistance.

TABLE 3. Statistical analysis of the measurements from the depth interval $0.2 \div 1.0 \mathrm{~m}$

\begin{tabular}{|l|c|c|c|c|c|c|}
\hline Soil column & Parameter & Min & Max & Range & Average & $S D$ \\
\hline \multirow{2}{*}{ Column 1 } & $Q_{t A} / Q_{t C}$ & 0.84 & 2.30 & 1.46 & 1.73 & 0.30 \\
\cline { 2 - 7 } & $Q_{t A}^{c o r} / Q_{t C}$ & 0.55 & 1.28 & 0.73 & 1.01 & 0.16 \\
\hline \multirow{2}{*}{ Column 2 } & $Q_{t A} / Q_{t B}$ & 1.00 & 2.20 & 1.20 & 1.79 & 0.34 \\
\cline { 2 - 7 } & $Q_{t A}^{c o r} / Q_{t B}$ & 0.62 & 1.14 & 0.52 & 0.94 & 0.15 \\
\hline
\end{tabular}




\section{CONCLUSIONS}

In the view of previously published in situ test results and results of this study confirm the fact that the saturation of sandy soils is important and it seems to be necessary to consider while conducting and interpreting CPTU test results. This is especially relevant for data obtained in the active zone, which follows the dynamic changes of soil saturation due to external factors, such as rainfall and evapotranspiration. Especially, saturation should be taken into account during rendering data from shallow depths obtained after a long dry season, when the thickness of unsaturated soils is elevated. The measurements have shown that the change of the soil moisture content influences both cone resistance $\left(q_{t}\right)$ and sleeve friction $\left(f_{s}\right)$. The values measured in unsaturated sands can be twice as large, which may lead to an twofold overestimation of the geotechnical design parameters. Changes of the measured penetration parameters in the active zone due to the influence of climate factors should be taken into account in the estimation of geotechnical parameters. Thus, a simple equation was proposed to correct the values obtained in unsaturated conditions. For the performed tests, the proposed relationship bring the results closer to the reference value (measurements in fully saturated conditions) resulting in a significant improvement of the results. However, its usability and limitations need revision and further research.

\section{REFERENCES}

AHMADI M.M., ROBERTSON P.K. 2008: A Numerical Study of Chamber Size and Boundary Effects on CPT Tip Resistance in NC Sand. Scientia Iranica 15 (5), $541-$ -553 .

BAŁACHOWSKI L. 2006: Penetration resistance of Lubiatowo sand in calibration chamber tests. Arch. of Hydro-Engineering Environ. Mech. 53 (4): 311-329.

BAŁACHOWSKI L. 2015: Interpretacja sondowania statycznego $\mathrm{w}$ pełnym zakresie głębokości. Inż. Mor. i Geotech. (5), 727-731.

BAŁACHOWSKI L., KUREK N. 2008: Influence of boundary conditions in calibration chamber. Arch. Civil Eng. 54 (4).

BOLTON M.D., GUI M.W. 1993: The Study of Relative Density and Boundary Effects for Cone Penetration Tests in Centrifuge. Cambridge University, Cambridge.

COLLINS R., MILLER G. 2014: Cone Penetration Testing in unsaturated soils at two instrumented test sites. CRC Press, 1489-1494.

EN ISO 22476-1, 2009: Geotechnical investigation and testing. Field testing. Part 1: Electrical CPT and CPTU.

EN ISO 22476-12, 2007: Geotechnical investigation and testing. Field testing. Part 1: Mechanical cone penetration.

GHIONNA V., JAMIOLKOWSKI M. 1991: A critical appraisal of calibration chamber testing of sands. Proceedings of the $1^{\text {st }}$ International Symposium on Calibration Chamber Testing, Potsdam. Elsevier, New York, 13-39.

GUI M.W., BOLTON M.D. 1998: Geometry and Scale Effects in CPT and Pile Design. Atlanta, Georgia, 2, 1063-1068.

GUI M.W., BOLTON M.D., GARNIER J., CORT'E J.F., BAGGE G., LAUE J., RENZI R. 1998: Guidelines for cone penetration tests in sand. T. Kimura et al., (Eds) Centrifuge'98, Tokyo, Balkema, 1, 155-160.

JAMIOLKOWSKI M., LO PRESTI D., MANASSERO M. 2003: Evaluation of Relative Density and Shear Strength of Sands from CPT and DMT. American Society of Civil Engineers, 201-238. doi:10.1061/40659(2003)7. 
LECH M., BAJDA M., MARKOWSKA-LECH K. 2008: The use of resistivity and seismic cone penetration tests for site characterization. Ann. Warsaw Univ. of Life Sci. - SGGW, Land Reclam. 40 (1), 87-96.

LEHANE B.M., ISMAIL M.A., FAHEY M. 2004: Seasonal dependence of in situ test parameters in sand above the water table. Géotechnique 54 (3), 215-218.

LUNNE T., POWELL J.J.M., ROBERTSON P.K. 1997: Cone Penetration Testing in Geotechnical Practice. CRC Press, London:.16.

MAYNE P.W. 2006: In-situ test calibrations for evaluating soil parameters. Taylor \& Francis. doi:10.1201/NOE0415426916. $\operatorname{ch} 2$.

MAYNE P.W., KULHAWY F.H. 1991: Calibration chamber database and boundary effects correction for CPT data. Proceedings of the $1^{\text {st }}$ International Conference on Calibration Chamber Testing, Clarkson University, Potsdam, USA, 257-263.

MŁYNAREK Z. 2007: Site investigation and mapping in urban area. Proceedings of $14^{\text {th }}$ European Conference on Soil Mechanics and Geotechnical Engineering, Madrid, 175-202.

MŁYNAREK Z., GOGOLIK S., POLTORAK J. 2012: The effect of varied stiffness of soil layers on interpretation of CPTU penetration characteristics. Arch. Civil Mech. Eng. 12 (2), 253-264.

MŁYNAREK Z., WIERZBICKI J. 2007: Nowe możliwości i problemy interpretacyjne polowych badań gruntów. Geologos 11, 97-118.

PHILLIPS R., VALSANGKAR A.J. 1987: An Experimental Investigation of Factors Affecting Penetration Resistance in Granular Soils in Centrifuge Modelling. University of Cambridge Department of Engineering, Cambridge.

PN-EN 1997-1, 2008: Eurokod 7. Projektowanie geotechniczne. Część 1: Zasady ogólne.

PN-EN 1997-2, 2009: Eurokod 7. Projektowanie geotechniczne. Część 2: Rozpoznawanie i badanie podłoża gruntowego.
POURNAGHIAZAR M., RUSSELL A.R., KHALILI N. 2010: CPT in unsaturated soils using a new calibration chamber. $2^{\text {nd }}$ International Symposium on Cone Penetration Testing, Huntington Beach, California, USA.

POURNAGHIAZAR M., RUSSELL A.R., KHALILI N. 2011: Development of a new calibration chamber for conducting cone penetration tests in unsaturated soils. Can. Geotech. J. 48 (2), 314-321.

POURNAGHIAZAR M., KHALILI N., RUSSELL A.R. 2013: The cone penetration test in unsaturated sands. Géotechnique 63 (14), 1209-1220.

ROBERTSON P.K. 1990: Soil classification using the cone penetration test. Can. Geot. J. 27 (1), 151-158.

ROBERTSON P.K., CAMPANELLA R.G. 1983: Interpretation of cone penetration tests. Part I: Sand. Can. Geotech. J. 20 (4), 718-733.

RUSSELL A.R., POURNAGHIAZAR M., KHALILI N. 2010: Interpreting CPT results in unsaturated sands. $2^{\text {nd }}$ International Symposium on Cone Penetration Testing, Huntington Beach, CA, USA.

SALGADO R., MITCHELL J.K., JAMIOLKOWSKI M. 1998: Calibration Chamber Size Effects on Penetration Resistance in Sand. J. Geotech. Geoenv. Eng. 124 (9), 878-888.

SANGLERAT G. 1972: The penetrometer and soil exploration. Interpretation of penetration diagrams - theory and practice. Elsevier Pub. Co, Amsterdam, New York.

SCHNAID F., HOULSBY G.T. 1991: An assessment of chamber size effects in the calibration of in situ tests in sand. Géotechnique 41 (3), 437-445.

TUFENKJIAN M.R., YEE E., THOMPSON D.J. 2010: Comparison of cone and minicone penetration resistance for sand at shallow depth. $2^{\text {nd }}$ International Symposium on Cone Penetration Testing, Huntington Beach, CA, USA, 2, 3 .

YANG H., RUSSELL A.R. 2013: Preparing unsaturated samples of decomposed granite for laboratory controlled CPTs. CRC Press, 191-196. 
YANG H., RUSSELL A.R. 2016: Cone penetration tests in unsaturated silty sands. Can. Geotech. J. 53 (3), 431-444.

Streszczenie: Wplyw wilgotności na wyniki sondowań statycznych $w$ piaskach średnich. Grunty zalegające płytko pod powierzchnią terenu znajdują się pod stałym wpływem czynników zewnętrznych, które mają wpływ na ich właściwości. Dynamiczne i niekontrolowane zmiany parametrów gruntowych wywołane np. zmianami wilgotności w skutek opadów i ewapotranspiracji mogą wpływać na wyniki i interpretację badań terenowych. W artykule przedstawiono wpływ zmiany wilgotności gruntów piaszczystych na wyniki sondowań statycznych CPTU. W tym celu wykonano model terenowy, w którym przeprowadzono pięć sondowań CPTU na kolumnach gruntu o różnej wilgotności. Podczas każdego sondowania wykonywano pomiary oporu stożka, tarcia na tulei oraz ciśnienia wody w porach $\left(u_{2}\right)$.
Dodatkowo po każdym sondowaniu określono rozkład wilgotności $\mathrm{w}$ próbce $\mathrm{z}$ wykorzystaniem czujnika TDR. W artykule pokazano różnice między parametrami uzyskiwanymi z badań CPT $\mathrm{w}$ gruntach piaszczystych $\mathrm{w}$ stanie niepełnego oraz pełnego nasycenia wodą. Dodatkowo zaproponowano prostą zależność umożliwiającą korektę oporu stożka z uwzględnieniem wpływu stanu nasycenia gruntu.
Authors' addresses:
Łukasz Zawadzki, Marek Bajda
Katedra Geoinżynierii
Wydział Budownictwa i Inżynierii Środowiska
SGGW
ul. Nowoursynowska 166, 02-787 Warszawa
Poland
e-mail: lukasz_zawadzki@sggw.pl, marek_bajda@sggw.pl 